\title{
TOWKAYS AND TYCOONS: THE CHINESE IN INDONESIAN ECONOMIC LIFE IN THE 1920S AND 1980s
}

\author{
Jamie Mackie
}

Since the nationalization in 1957-1958 of the Dutch business enterprises that had dominated the colonial economy, including most of the country's largest plantations, mines, banks, and business houses, many Chinese firms previously confined to an intermediate position in the "colonial caste structure," as Wertheim has called it," have been able to advance to the topmost ranks in the present economic structure of Indonesia. Collectively, they now overshadow the previously dominant state sector made up largely of those nationalized enterprises. The two largest Chinese firms, Liem Sioe Liong's vast conglomerate and William Soeryadjaya's Astra Corporation, hold assets that were estimated to be worth Rp. 6.4 trillion and Rp. 2 trillion respectively (US\$3.5 billion and $\$ 1.2$ billion) in 1988, whereas ten others are in the $\$ 400-\$ 700$ million range and another one hundred or so exceed the $\$ 100$ million mark. ${ }^{2}$ By any measure, international as well as local, the foremost of these men can aptly be called tycoons, "businessmen of extraordinary wealth and power," in the dictionary definition, whose wealth far exceeds that of their predecessors earlier in the century, Dutch as well as Chinese. In contrast, none of the wealthiest Chinese towkay of the 1920s (a word that refers rather indeterminately to "a Chinese big businessman," although not always an especially rich one) could have been compared with the big Dutch capitalists of the colonial era, apart from the almost legendary Oei Tiong Ham, to whom I will return shortly. ${ }^{3}$

Most explanations of how and why this transformation has occurred tend to fall somewhere between two rival camps. On one side are the structural and class interpretations,

\footnotetext{
${ }^{1}$ W. F. Wertheim, Indonesian Society in Transition (The Hague: Van Hoeve, 1956), chap. 6.

${ }^{2}$ Figures based on Warta Ekonomi, 5 (5), (July 1989): 72, and Conglomeration Indonesia. A Profile of Indonesia's Largest Business Groupings, ed. Christianto Wibisono (Jakarta: Pusat Dokumentasi Business Indonesia, 1990). Although all such estimates of company assets must be treated with reserve, these are probably adequate to indicate approximate orders of magnitude.

${ }^{3}$ Definitions of towkay and tycoon are taken from Mary Somers-Heidhues, Southeast Asia's Chinese Minorities (Hawthorn, Vic.: Longman Studies in Contemporary Southeast Asia, 1976), p. 114, and Webster's New Collegiate Dictionary, respectively.
} 
which weight the close relationships the new tycoons have developed with the New Order political and military authorities. At the other extreme are those explanations that stress ethnic and cultural factors or simply take for granted that the commercial successes of the Southeast Asian Chinese more generally are owing to their seemingly ingrained advantages over their indigenous rivals in business skills and motivations. Both approaches have much to be said for them, and both have their weaknesses; neither is entirely adequate in itself. A complex interplay of ethnic and class factors has shaped the development of Chinese business enterprises in Southeast Asia over the last century or more, which is not easily reduced to one-dimensional generalizations at any stage. To understand the processes involved one needs ideally to be able to trace the evolution of the economic roles of particular Chinese businessmen, or broad groups of them, in the particular historical and sociopolitical contexts of their times. That is not easy, however, for it is difficult to get adequate biographical or historical information about even the better-known of them, let alone the more obscure and poor Chinese who remain in the shadows. All one can do is draw inferences from the lives of the few wealthy figures, both past and present, whose stories have been recorded.

In an attempt to sketch changes in the economic situation and roles of the Sino-Indonesian minority as a whole during this century, I will focus here on the two men about whose careers information is most fully available, Oei Tiong Ham and Liem Sioe Liong. ${ }^{4}$ Because both were outstandingly successful and wealthy, they cannot be regarded as representative of Chinese businessmen in general, let alone of the entire Chinese minority. But if one can identify the factors that made these men so successful, one may find clues to the successes or failures of others.

One must be wary of the stereotypical notion that the Southeast Asian Chinese have long been predominantly traders because some superior aptitude for commerce and smallscale industry was lacking among the indigenous peoples. It was really only from about the 1920 s onward that large numbers of Chinese in Indonesia began to move away from other occupations, mostly less desirable ones, as in the case of thousands of plantation and mining coolies, into what today are commonly regarded as their characteristic roles as small-scale traders, warung operators, commodity dealers, and money lenders. There had, of course, been significant numbers of Chinese in those roles in various parts of the colony long before the 1920s, but they were then far less widely or thickly spread geographically, and fewer engaged in petty trade than those in later periods. Since the $1920 \mathrm{~s}$, however, they have become almost ubiquitous in those roles. The changes in occupations and economic roles that unfolded between 1900 and 1930 (arrested by the onset of the Great Depression, which caused the cessation of large-scale Chinese immigration) must be seen as the beginning of a long process of adjustment and adaptation to constantly evolving economic and political conditions that can be traced to the present day.

The splendid picture James Rush has given in this volume of the extensive networks or pyramids of Chinese patrons and clients that were established around the great opium concessions (farms) held by the opium "kings" in central and eastern Java in the latter half of the nineteenth century provides us with a good starting point for this story slightly farther back in time. Many of the lower-level participants in that business must have been petty traders in small towns who dealt in opium inter alia through those networks. But because of

\footnotetext{
4The term "Sino-Indonesian," rather than "Indonesian Chinese," is used here in the contemporary context by analogy with the generally accepted term "Sino-Thai" to stress nationality not ethnicity. For the years before the 1960 s, when the dual nationality issue was still unresolved, the indefinite term "Chinese" is appropriate and more convenient.
} 
their involvement in the networks (frequently illegal and semicriminal in character, Rush observes) they were probably traders of a rather different type from the more modern shophouse owners who operate independently-and in most cases honestly-and who fanned out across entirely new areas of Java and the Outer Islands in the early decades of this century. Rush notes that in addition to the kings who controlled the opium farms, and their numerous retainers in the late nineteenth century, there were also many penniless newcomers and small-scale vendors and tradespeople among the Chinese, who never earned more than modest incomes or rose above menial occupations. But they were nowhere near as numerous or widespread at that time as they became by the $1920 \mathrm{~s}$. The big money was in opium until the economic crisis of the 1880 s, the product that seems to have attracted the most enterprising or acquisitive of the Chinese with substantial capital. Others, although not many, were engaged in commodity trading and in cultivation, particularly of sugar and tobacco, from much earlier in the century. Most were not yet large-scale operators, however, and if big fortunes were made in these sectors, they did not lead to the emergence of families as wealthy as those produced by the opium trade.

What Rush calls the "dance of collaboration" between the Chinese opium kings and the local Dutch and Javanese officials, especially his observation that the former were located physically close to the powerholders and "nested within the power structure," has much in common with the kinds of relationships that prevail today between leading Chinese capitalists and Indonesian powerholders, both in Jakarta and in the provincial capitals and smaller towns throughout the country. But this system disintegrated in the 1890 s, he tells us, as the opium farms collapsed financially, and the authority of the peranakan (locally born) elite families waned under the impact of a new wave of totok (China-born) immigrants. The economic roles of the Chinese and the character of the various Chinese communities changed significantly over the next forty years as did the entire colonial economy, owing to the vigorous expansion of the Dutch plantation system and the much higher investment levels in all fields between the 1890s and 1929.

\section{Chinese Business in Indonesia in the 1920s}

Patterns of Chinese business activity in many parts of the colony were transformed in the years between the collapse of the opium farms in the 1880s and the 1920s, the last prosperous decade before the Great Depression, which brought a radically new set of changes. This was a time of rapid increase in the Chinese population, owing to a high rate of immigration, primarily of indentured laborers for the Sumatran plantation industries. ${ }^{5}$ One result was a widening rift within Chinese society between the peranakan and totok communities, both political and economic. At the same time, the dramatic expansion of the Dutch-dominated plantation economy severely constrained the scope of operation for the existing Chinese planters in the sugar and tobacco industries, although it opened up other trading opportunities for them as the plantation frontier expanded into new areas of Java and Sumatra. It was directly associated with an increase in the number of small Chinese warung owners scattered throughout the archipelago. A detailed diachronic account of the economic processes and sociocultural dynamics underlying the changes then taking place would be an illuminating supplement to the several rather static accounts available of Chinese business activities in the last years before World War II. A few of the more prominent individuals who emerged as business leaders are identifiable, but, with the exception of the

\footnotetext{
${ }^{5}$ The Chinese population of the colony rose from 344,000 to 800,000 between 1880 and 1920 , then to $1,233,000$ in 1930. For fuller details, see J. A. C. Mackie, "The Geographical Dispersal and Occupations of the Indonesian Chinese, 1900-1930," Asian Culture (Singapore), 14 (April 1990): 5-22.
} 
biggest towkays like Oei Tiong Ham, Tjong A Fie, and a handful of others, little is known of their business careers.

The disintegration at this time of the symbiotic relationship between wealthy Chinese businessmen and colonial officials noted by Rush was attributable not just to the collapse of the opium kings but also to the fact that the Chinese now found themselves more generally under pressure, even under attack, by the Dutch authorities as exploiters of the native people, a popular theme of Ethical Policy reformers. The point can be carried even farther into the present century. The Chinese minority was regarded with hostility, or at least suspicion, by the various state authorities in Indonesia not only through the last half-century of colonial rule but also throughout the next thirty years of Japanese occupation, the revolution, and the early years of independence. Only since the 1970s has something like that earlier symbiotic relationship with the ruling elite been reestablished. The general thrust of government policy during the period of rapid expansion of the Dutch plantation economy between 1900 and 1930 was to exclude Chinese and indigenous producers from participation in that sector lest they disturb the Dutch planters' access to land, labor, and markets at minimum costs.

Only one Chinese firm succeeded in competing with the Dutch on their own ground at this time, the Oei Tiong Ham Concern. Its story throws light on the scope of and limits upon Chinese big business during that late colonial period of rapid economic expansion, although Oei was quite unlike other Chinese businesssmen of that time in many respects. In his early years he was one of the last of the old-style opium kings, yet he soon transformed himself into a new-style modern capitalist using business techniques similar to those of the Dutch. Oei thus became one of the few Chinese who survived in the fiercely competitive business of sugar cultivation; he also succeeded in establishing a set of mills that were among the most modern and efficient in the colony, which at the time was the most technically advanced sugar producer in the world. He was a remarkably innovative and forward-looking businessman by any standard.

Born in Semarang in 1866, Oei Tiong Ham was the son of a moderately well-to-do, educated Chinese who had fled to Java not long before, after the collapse of the Taiping rebellion in which he had participated. Oei's father, although penniless on his arrival in Semarang, was soon able to build his sugar trading company, Kian Guan. This firm persisted as the core component of the family business until the 1950s, a record in longevity for a major Indonesian Chinese firm. His son, Oei Tiong Ham, was brought into the firm after a period of Chinese-language schooling. By the age of twenty-four, after being appointed lieutenant of the Chinese in Semarang, he was not only managing the firm but was also involved in the opium farm business, presumably by virtue of the standing of his family at that time. ${ }^{6}$

The early stages of Oei Tiong Ham's career and the reasons for his initial success are still obscure. There are several legendary stories about him during this period: that he was a heavy gambler who nearly lost a large sum of his father's money at one point but was saved by the generosity of an old Chinese lady who had confidence in him; and that he was bequeathed a substantial legacy by an old German living in one of his father's houses in Semarang who had taken a liking to him, which enabled him to purchase his first sugar plantation. Regardless of the truth or fantasy behind these anecdotes, it is clear that the most important of these early steps in career advancement must have been his decision to buy several sugar plantations in the early 1890 s at a time when the industry was just beginning

${ }^{6} \mathrm{~A}$ useful set of biographical studies on which I have drawn here is compiled in Yoshihara Kunio, ed., Oei Tiong Ham Concern: the First Business Empire of Southeast Asia (Kyoto: Centre for Southeast Asian Studies, 1989). 
to emerge from its severe 1880 s slump, while values were still depressed. In the following years, sugar prices, demand, and production rose steadily so that the five plantations he acquired soon became the basis of a strong, well-integrated group of companies extending from sugar production and trading to a shipping company, warehouses, a bank, and overseas trading offices. It seems unlikely that the opium farm was an especially critical element in his growing fortune because the opium trade was declining by the $1890 \mathrm{~s}$. In any case, his family was already quite well off, so the capital needed to build up his business enterprise was not difficult to acquire. But what made him such an outstanding businessman for his time was the way he ran his business once he got started, for in this he was quite untypical of other Chinese businessmen of the late colonial era.

The key factor in his commercial success seems to have been an awareness of the need to adopt Dutch business methods and technical skills combined with a shrewd sense of timing in his purchases and sales. In the latter respect he was perhaps not very different from other Chinese traders of his time, but he was far ahead of them in the former (although it is puzzling that no others followed him on that score). One of his mills was the first in Java to be electrified. He employed Dutch mill technicians, accountants, and lawyers extensively, and also used Dutch-trained Chinese with similar qualifications in due course. He avoided excessive diversification into activities unrelated to his sugar-based enterprise, although Kian Guan's overseas trading interests expanded and diversified considerably after World War I.

Oei Tiong Ham's relations with the Dutch authorities appear to have been reasonably cordial but never particularly close, not at all comparable with the symbiotic relationships with national political leaders that later developed in the 1970s and 1980s. He did not speak Dutch and appears not to have associated socially with Dutch officials in Semarang, although he entertained lavishly, including visiting state guests such as King Chulalongkorn. Yet he received little help from the government and was sufficiently outraged by its imposition of a stiff excess profits tax on him after he had made a killing from the steep increase in sugar prices during World War I that he moved permanently to Singapore in protest. He died there, still in his fifties, in 1924.

Although the Oei Tiong Ham Concern survived his death and continued to operate into the 1950s under the leadership of the two most competent of his many sons (he had twentyfive children in all), it gradually became a less successful business enterprise and was finally nationalized in 1961 after running into political problems with the Sukarno government. It survived the difficult years of depression, World War II, and the struggle for independence that followed with only moderate setbacks but faced increasing problems in adapting to the radically different conditions that emerged after independence. Above all, it was weakened at that critical juncture by the universal problem of generational change within a Chinese family firm, which gave rise to debilitating intrafamily disputes in the 1950 s over matters of control and business strategy. It is hard to avoid the conclusion that leadership and personality factors were crucially important in both the rise and decline of this first great Indonesian Chinese corporate enterprise.

None of the other leading Chinese merchant families of the early twentieth century achieved anything like the eminence of Oei Tiong Ham. His nearest rival was Kwik Hoo Tong, a very successful trader in sugar and other agricultural commodities during the boom years of the 1920s (until he went bankrupt) also based in Semarang. (The prominence of Semarang Chinese at that time is interesting, for the only Chinese firms that actually cultivated plantation crops in East Java, where the biggest Dutch agricultural enterprises were concentrated, seem to have been much smaller than those in Central Java.) Kwik's company did not compete directly with modern Dutch enterprises in plantation agriculture, however. 
He was more an old-style towkay than a modern tycoon. Much the same could be said of the famous Tjong A Fie, an influential Kapitien der Chineezen in Medan, who had diverse business interests and close relations with the Dutch local authorities but no particular and enduring base to his enterprise comparable to that of Oei.?

A few Chinese planters cultivated sugar and other plantation crops in Java on a small scale until the 1920s, but none approached the stature of the Oei Tiong Ham Concern. The expansion of large Dutch corporate plantations from the 1880 s on crippled the embryonic class of Chinese sugar and tobacco planters who had previously been able to compete against Dutch planters in significant numbers at a time when most of those enterprises were quite small and rudimentary, generally between 17-30 ha. for sugar or 3.5-7.0 ha. for tobacco. But the introduction of large steam-driven sugar mills required huge capital outlays and a vast expansion in the size of sugar plantations during the last quarter of the nineteenth century; most of them were between 350-700 ha. and some of the largest were twice that size. Small privately owned plantations merged into larger ones during the consolidation and corporatization that accompanied the severe slump in the sugar industry in the mid-1880s. Only a handful of Chinese mills were able to survive under those circumstances-Oei Tiong Ham's the foremost among them, along with several much smaller ones-but the latter all collapsed soon after the onset of the depression of the 1930s.

For tobacco and other cash crops, consolidation was less dramatic but equally devastating to the few Chinese planters who survived on the fringes of the plantation economy into the 1920s. (In rice milling and trading, however, they became dominant at about this time for the Dutch were never significant competitors there.) Few if any Chinese planters were able to establish large-scale rubber plantations during the rubber booms of the early twentieth century, although many Chinese played important roles as traders and rubber remillers in the fast-expanding indigenous smallholder rubber industry of South Sumatra and elsewhere. ${ }^{8}$ Government policy was less important than technological and financial factors in bringing about their exclusion from the Dutch-dominated plantation sector, but there is no doubt that the colonial economy no longer needed Chinese participation in that sector as it had in the mid-nineteenth century. Whereas the larger Chinese plantations of the nineteenth century had been able to compete with their Dutch rivals, they were increasingly forced out of business in the early twentieth century. Thus Chinese capitalists in Java found it easier to survive in fields like retail trading and petty industries, where they were competing only with Indonesians.

One other factor that affected the pattern of economic roles at that time was the change in the character of the Chinese population: the number of China-born (totok) members increased sharply. This increase resulted from the very high immigration rates of the 1920s, mostly to Sumatra but also to Java. Many of these newcomers, nearly all single men, became petty traders or artisans, often in the more remote rural areas where peranakan had been reluctant to operate. Many others moved into the newly expanding plantation areas of Java or rubber-growing areas of Sumatra where business opportunities were most plentiful. The totok were almost solely responsible for the great expansion of Chinese commercial enterprise across Indonesia in the early twentieth century, taking on the classic economic roles with which they have been most commonly associated since then. Few peranakan were

\footnotetext{
${ }^{7}$ See Onghokham, "Chinese Capitalism in Dutch Java" in Yoshihara, Oei Tiong Ham Concern, pp. 50-71; he mentions also the Be, Liem, and Tan families in Semarang and the Han, Kwee, Tjoa, and The families in Surabaya as the foremost to produce Chinese officers and revenue farmers over long periods.

${ }^{8}$ See K. D. Thomas and J. Panglaykim, "The Chinese in the South Sumatran Rubber Industry: A Case Study in Economic Nationalism," in The Chinese in Indonesia: Fize Essays, ed. J. A. C. Mackie (Melbourne: Nelson, 1976).
} 
attracted toward the risks and discomforts of such activities; their greater access to education and a more settled lifestyle inclined them toward salaried and professional jobs, wherever possible. ${ }^{9}$

It is surely not coincidental, therefore, that a high proportion of the most dynamic and successful Chinese businessmen who have emerged in Indonesia since that time have been either China-born or from totok family backgrounds. They have pushed aside the old peranakan families and often bought up their old-style mansions. Although they had little scope for dramatic expansion or enrichment during the forty years of disruption and stagnant economic conditions that followed the onset of the depression in 1930, many were able to survive those years more successfully than the peranakan. When favorable economic conditions returned after about 1970, these men were well placed by experience and adaptability to seize the rich opportunities for business expansion that arose in the Suharto era.

\section{Disruptions and Transitions, 1930-1965}

During the twenty years covering the depression, Japanese occupation, and struggle for independence, many of the Chinese in Indonesia were forced to move into new and different economic roles-or in a few cases now found themselves able to do so-as the economy underwent a series of major upheavals that shattered the old colonial economic structure. New types of industries developed in the 1930s, most of them quite small and predominantly Chinese owned (e.g., textiles, food processing, soap, cigarettes), as the colony's capacity to import shrank drastically and protective barriers created new markets. As the Dutch-owned businesses that had dominated the modern sector of the economy collapsed or contracted, there was more space for Chinese businessmen to move into their places, especially during the 1940 s. But their opportunities for upward social mobility were still effectively closed by the economic dominance of the Dutch over the huge plantation sector and the capital-intensive banking, financial, and commercial spheres, a state of affairs that continued into the late 1950 s, well after Indonesia had proclaimed her independence. No fundamental reshaping of the patterns of ownership and control of the country's productive resources occurred until 1957-1958, when all Dutch enterprises were suddenly nationalized at a tense moment in the struggle to recover West Irian.

The elimination of the Dutch opened new opportunities for the wealthier Chinese to take their places in various niches along the higher slopes of the commanding heights of the economy, but as the nationalized enterprises were almost wholly state controlled and private enterprise generally was under an ideological cloud in the era of President Sukarno's "Socialism à la Indonesia," the Chinese did not gain very dramatically from the new situation until after the New Order regime took over in 1965-1966. The steadily intensifying economic and administrative decline of 1958-1965 meant that everyone in the country was living more or less hand-to-mouth, from one crisis to the next. Almost no significant new investment was occurring to stimulate economic activity, and real incomes per capita were declining in most regions. Many Chinese were able to cope with these conditions more skillfully than indigenous Indonesians, thanks to their greater commercial experience, but few became especially rich at this time. At best, they were treading water.

No new tycoons of any real substance emerged during those troubled decades-Mas Agung was the nearest approach to one, perhaps, but was not yet the wealthy tycoon he became later-although some Chinese got rich by smuggling goods to Singapore and else-

\footnotetext{
${ }^{9}$ See David Willmott, The Chinese of Semarang (Ithaca, N.Y.: Cornell University Press, 1960), chap. 3. For further
} details on occupations and location, see Mackie, "Geographical Dispersal." 
where during the 1940s and by engaging in "barter trade" (a euphemism for smuggling at a time of high black market foreign exchange rates) in the 1950s. Many of them took their money, and often their families and entire businesses, to Singapore or Malaysia. Because of the generally stagnant condition of the economy throughout those decades, there were few opportunities to tap expanding markets and thereby build substantial business empires as in the earlier years of the century or in the post-1970 period. Even the old, established family firms found it difficult to survive in those circumstances, and many of them collapsed during the war and revolution, particularly those that had depended heavily on Dutch suppliers or customers. According to Twang Peck-yang, the businessmen who succeeded best in the disrupted circumstances of the 1940s had small small businesses and the ability to adapt. Of these, members of the Hok-cia subgroup were the most outstanding. One of them was Liem Sioe Liong. ${ }^{10}$

Above all, the political vulnerablity of the Indonesian Chinese was worse than at any other time during those middle decades of the century, particularly in the unsettled conditions of the Japanese occupation and the revolution, when anti-Chinese violence was widespread. The strong nationalist sentiments aroused by the struggle for independence were directed against the Chinese as well as the Dutch, at times fanned by right-wing groups against which neither President Sukarno nor the Communist party, the only political forces inclined to defend them, were able to mount any effective defense. There was almost no scope for the kinds of close conections with the political authorities that have characterized the New Order, or the earlier relationships described by Rush between the opium kings and the colonial authorities.

\section{Sino-Indonesian Businessmen under the New Order}

The earliest years of the New Order were a period of terrifying insecurity and spasmodic violence for the Indonesian Chinese. The victors in the 1965-1966 power struggle were the very people who had earlier been their most feared enemies, the military and the Muslim right wing. ${ }^{11}$ It would scarcely have been imaginable in 1966-1967 that anti-Chinese antagonisms in the society would soon be damped down almost completely by the military authorities or that within twenty years the Chinese would be prospering as they have in the vanguard of the country's "economic miracle." Least of all was it then foreseeable that the foremost of the big Chinese towkays would be able to grow so extraordinarily rich in an intimate alliance with the new military-political elite.

It is worth posing the hypothetical question whether that pattern of alliance would ever have been achieved without an accident of history, if only to underline what a crucially important and fortuitous quirk of fate it was: President Suharto and Liem Sioe Liong quickly began to build an enduring relationship on the basis of the slender personal and financial links first established between them in Central Java many years earlier. The businessman who was destined to become the greatest tycoon in the nation's history, thanks to that relationship, happened already to have achieved a degree of mutual trust with the man who was destined to become president (and remain so for a quarter-century). The personal element in the president's relationship with Liem seems to have been enormously important

\footnotetext{
${ }^{10}$ The Hok-cia are a small but unusually interesting subgroup of immigrants from Fujian, reputedly very closeknit, who proved highly successful as traders and smugglers during the years 1945-1949. A disproportionate number of them are now prominent among Indonesia's businessmen; see Twang Peck-yang, "The Transformation of the Trading Minorities in Indonesia, 1940-50" (Ph.D. diss., Australian National University, 1988).

${ }^{11}$ See Charles Coppel, Indonesian Chinese in Crisis (Kuala Lumpur: Oxford University Press, 1983) and J. A. C. Mackie, "Anti-Chinese Outbreaks in Indonesia, 1959-1968," in Mackie, Chinese in Indonesia, chap. 3.
} 
from the beginning right down to the present. Someone else might have been equally able to fill Liem's shoes, for instance, one of the various other cukong who became notorious around 1970-1971 because of their financial connections with various military and political leaders, not solely President Suharto. ${ }^{12}$ But one suspects that it would have been a significantly different kind of relationship, with Suharto the intensely reserved kind of man he is and trust one of the key values for old-style Chinese like Liem. ${ }^{13}$ The consequences, too, might have been quite different, at least in the early unsettled years of the New Order. Of the dozen or so cukong most commonly mentioned at that time, only Bob Hasan has achieved the same intimacy of access to the president and his family as Liem, and that fairly recently after he established the powerful grip over the timber and forest products industries that he has had since 1980. William Soeryadjaya, the second largest of the tycoons, has never had links as close with the palace as those of Liem, according to Jakarta gossip, nor have any of the other top ten tycoons.

What matters in the long run, however, is not so much the accidents of personality involved, important though they appear to have been here, but the structural ties that have bound together the two elements. On one side are the Sino-Indonesian business enterprises with their money and commercial skills, which were desperately needed in the early years of the New Order; on the other side are the military and political leaders of the new regime, with their capacity to supply protection and social stability, creating a tight symbiotic relationship that had been impossible prior to 1965. Yet that kind of alliance might not have developed as it did if the political structure established by the initially loose New Order coalition of military and civilian elements that overthrew Sukarno had resulted in a more pluralistic or less state-dominated system, one in which political parties and other social groups might have been able to play a larger part, instead of the highly centralized and increasingly authoritarian, patrimonialist structure that came into being in the early $1970 \mathrm{~s}^{14}$ It was not a predetermined outcome but one shaped by the political struggles of the years 1966-1974. The political vulnerability of the Chinese during those years combined with that precarious political balance and the straitened economic circumstances of the late 1960 s all stacked the odds heavily toward the emergence of some such pattern of relationships.

The government's decision to reverse the economic policies of the Sukarno era and to embark on a market-oriented economic strategy could not have succeeded, however, unless the way was opened for the Chinese to participate as fully as possible in economic life because they alone had the commercial experience and ready access to foreign capital. Their contribution to the economic transformation of the country since 1966-1967 has far exceeded that of the pribumi businessmen and state enterprises. Yet the most distinctive feature of the

\footnotetext{
${ }^{12}$ Coppel gives the best account of these relationships in Indonesian Chinese in Crisis, pp. 153-54, defining a cukong simply as a "Chinese businessman in alliance with Indonesian power holders"; for lists of the names current in 1970-1971, see Leo Suryadinata, "Chinese Economic Elites in Indonesia: a Preliminary Study" in Changing Ethnic Identities of the Southeast Asian Chinese since World War II, ed. Jennifer Cushman and Wang Gangwu (Hong Kong: University of Hong Kong Press, 1988), pp. 261-88.

${ }^{13}$ See the discussion of sun yungi (Cantonese, "interpersonal trust" or "confidence," the key concept in business relations among Chinese), Clifton Barton, "Trust and Credit: Some Observations Regarding Business Strategies of Overseas Chinese," in The Chinese in Southeast Asia, ed. Linda Lim and J. A. Peter Cosling (Singapore: Marnuzen, 1983).

${ }^{14}$ See Harold Crouch, The Army and Politics in Indonesia (Ithaca, N.Y.: Cornell University Press, 1978) for the best account of political developments in the early New Order period. He has also used the term patrimonialism to refer to the political system as it developed in the late 1970s, with a high degree of concentration of both decisionmaking power and control over the allocation of key financial and economic resources (capital, bank credits, licenses, etc.) at the apex of the political structure.
} 
emergence of the big Sino-Indonesian conglomerates since that time has been the extent to which they have been able to benefit from deviations from free-market principles by taking advantage of privileged access to resources (particularly subsidized loans), quasi-monopoly situations, and rent-seeking opportunities. They have been able to leverage the huge profits generated from them into enormous capital gains. ${ }^{15}$

The consequences of this situation for the Sino-Indonesian community in general have been immense. Political connections and protection have been an almost essential condition of economic success for Indonesian businessmen of all races since early in the New Order, very blatantly so in some instances but never to be ignored entirely for Riggs's ugly term "pariah capitalist" is appropriate in Indonesia not only to the Chinese. At the same time, the entire Sino-Indonesian minority has been subject to various forms of discrimination and exclusion from educational, social, and employment rights, ostensibly on the grounds of promoting the economic advance of the pribumi, measures that the wealthy Chinese have been powerless to prevent or protest. (They avoid them by having their children educated overseas, at great expense to the country.) The net effect has been to keep the Chinese dependent, politically powerless, and easily controllable.

The huge corporate conglomerates that have come to dominate many areas of the country's economic life began to emerge in the early 1980s, after the momentum of development induced by the oil boom began to diversify the national economy dramatically for the first time since the 1920s. About one dozen of these groups are now outstandingly large and wealthy, whereas several hundred would exceed in size any of the earlier Chinese firms in Indonesia, except perhaps the Oei Tiong Ham Concern at its peak in the 1920s. Almost all are family firms rather than joint stock companies with multiple holdings, and all of them have been created by "new men" who have made their fortunes since the Suharto regime took over in 1965-1966. "Old wealth" is conspicuously absent at this level. Surprisingly few of the top thirty or forty firms have failed over the last twenty years, although most of them have relied on highly leveraged bank loans or speculative property dealings to provide the capital bases from which they have expanded. All have had to rely to some degree on political connections for privileges or protection.

It is much easier to put together a picture of the Sino-Indonesian big business class, impressionistic and blurred in many details though it may be, than it is to depict the SinoIndonesian minority as a whole or the condition of their scores of thousands of smaller business enterprises. It is probably true that nearly all Sino-Indonesians at every level of society have experienced substantial improvements in their standards of living (except in some rural areas, perhaps) as has the urban population in general. They now constitute a core element in the newly emerging Indonesian urban, educated middle class. But reliable statistical data are too scanty to enable one to sketch the socioeconomic conditions of the entire ethnic minority with any precision. Only by the crudest guesswork could one attempt to estimate how many adult Sino-Indonesians were engaged in business activities in the 1980 s or how many hold professional or salaried jobs or are still engaged in agricultural, fishing, or mining activities (as some are). It is well documented that very few indeed are employed in government service and that the educational levels of Sino-Indonesians are generally much higher than those of the indigenous people. In those respects the situation in the 1980 s does not differ greatly from that of the 1920s, except in degree. Citizenship, however, has undergone a fundamental change. Well over 90 percent of Sino-Indonesians are

${ }^{15}$ On rent-seeking capitalists, see Yoshihara Kunio, The Rise of Ersatz Capitalism in Southeast Asia (Singapore: Oxford University Press, 1988), pp. 3-4, 68-98. 
now Indonesian citizens, increasingly identified with the economic and social future of the country as the old links with China fray.

At this point it is appropriate to turn to the life story of Liem Sioe Liong for clues to the emergence of the great tycoons. But there is one big difference between Liem Sioe Liong and Oei Tiong Ham. For all his later eminence, Liem has had more in common with his peers than Oei did, except in the key factor of his close and long-standing relationship with the president. And like many of them, but unlike Oei, his life has been a classic case of the Horatio Alger rags-to-riches myth of a man who started from the very lowest rungs of the socioeconomic ladder and has ascended to the top. His story falls into two parts: an unremarkable life as an ordinary Indonesian Chinese trader during his first fifty years, followed by an utterly extraordinary rise to immense wealth over the last twenty years under the Suharto regime. ${ }^{16}$

Liem came to Central Java from Fujian in 1938, aged twenty, as an almost penniless immigrant, living and working initially with his brother in Kudus as a petty trader during the difficult years of the Great Depression and World War II. They started out in a form of rural small-scale hawking on a buy-now-pay-later basis, known as Cina mindering, to which many Hok-cias across Java had turned because, as one of the smallest of the Chinese emigrant groups and among the last to come to Java in any number, they were forced to find a livelihood in the less-favored occupations. Although their returns were small and the risks of loss high, the experience paid off in the disrupted conditions of Japanese occupation, war, and revolution that followed soon after for these traders were well acquainted with the countryside. They knew where to go for goods that were in short supply and had wideranging networks of former customers and clients who were obligated to them.

Soon after the Japanese took over, the mindering business was banned and Liem had to find other forms of small-scale trade to make a living, including trade in cloves for kretek factories. He did well enough even in those difficult times to be able to marry and move into better accommodations. He achieved a reputation for being hardworking, modest, and discreet and became sufficiently well regarded in both the local Chinese community and among the Indonesians to have his first great stroke of luck, which opened the way to his later fame and fortune. The local independence committee was asked to provide a refuge during the struggle for independence for a mysterious visitor from Jakarta. The visitor turned out to be Hassan Din, President Sukarno's father-in-law, for whom Liem's household was chosen as a safe haven. This twist of fate brought him into contact with various TNI military officers and established his credentials as a sympathizer with the republic and its leaders. As one result, he became a supplier to the Republican forces. He thereby established contact with officers of the Diponegoro Division, including Sudjono Humardani, later a close associate of Suharto, and he continued to supply various commodities to it throughout the 1950s. He claims, however, that he did not actually meet Lieutenant Colonel Suharto, as he was then known, until around 1952, several years before the latter was appointed military commander in Central Java and based in Semarang.

Supplying the armed forces was not Liem's only activity in those years for he continued to deal in cloves, importing them from the Outer Islands of Indonesia or from Singapore, in some cases smuggling them past the Dutch authorities. Risky though it was, this business must have been lucrative (kretek consumption was increasing steadily even then), and by the early 1950s, Liem's business activities had expanded sufficiently to make it worthwhile

\footnotetext{
${ }^{16}$ See Eddy Soetiyono, Kisah Sukses Liem Sioe Liong (Jakarta: Indomedia, 1989) and Sori Esa Siregar and K. T. Widya, Liem Sioe Liong: Dari Futjing ke Mancanegara (Jakarta: Pustaka Merdeka, 1989).
} 
to move his entire household to Jakarta. Thence he embarked upon a series of more substantial manufacturing ventures in both Jakarta and Semarang. Significantly, none of these was particularly successful at that time, although he still maintained his clove business in the Kudus-Semarang region. In the late 1950s, when Suharto was military commander in Semarang, Liem began to build his close relationship with him. The Semarang phase of his business career must have been quite important for him, although relatively little is known about it apart from the fact that he then acquired two small private banks including Bank Central Asia (BCA), which was later to become one of his crown jewels. Yet it made little money for him until 1975, when Liem was able to entice Mochtar Riady to leave a rival bank and manage $\mathrm{BCA}$; he rapidly turned it into the money-spinner it has since become.

Prior to 1965, Liem was a moderately successful Jakarta businessman, but not at all an outstanding or well-known one. His story would until then have been broadly similar to those of many other Chinese towkays in Indonesia at that time. But he rocketed into prominence soon after Suharto became president, obtaining highly controversial monopoly rights to import cloves (along with Probosutedjo, the president's half-brother, who has shown little love for him in later years) and to manufacture flour, the springboard from which his other business interests, many in conjunction with members of the Suharto family, rapidly expanded. All this gave rise to widespread criticism of him as the foremost of the notorious cukong said to be bankrolling the new regime from behind the scenes, to a point where his close associations with members of the Suharto family circle soon became public scandal. But the president simply disregarded the criticism, and Liem survived unscathed, even during the anti-Chinese outbreaks known as the Malari affair in 1974.

Liem's business empire began to grow rapidly in the early 1970 s as he diversified his investments into general trading, real estate, textile manufacturing, crumb rubber milling, and logging, all of them fast-growing sectors of the Indonesian economy when it recovered from its mid-1960s chaos. His achievements in these fields were not especially remarkable, however, and in several other sectors his record was curiously checkered. He was relatively slow to enter the profitable motor vehicle assembling industry, long after the Astra and Krama Yudha groups had established strong positions there. His banking enterprises were not at all successful until after 1975, when Mochtar Riady was brought in to manage BCA. From then on, BCA rose rapidly to become the most dynamic of the private banks, with a string of associated insurance and financial enterprises attached to it; but the credit for that is attributable more to Riady, who is generally regarded as an outstanding banker, than to Liem himself.

In the early 1980s, Liem's business interests were already estimated to be worth more than US $\$ 2$ billion, and he was branching out into several offshore investments, of which the Hong Kong-based First Pacific group was in time to prove highly successful. But he also had serious problems in the 1980 s, most notably his loss-incurring involvement (imposed upon him by the president in return for other favors) in the government-owned Krakatau Steel complex and the overextension of his huge Indocement group of cement factories, which had to be bailed out by the government at the cost of billions of rupiah during the slump of 1984-1985.

One cannot help wondering, in light of these episodes, whether Liem's great fortune has been due to his outstanding business acumen (as Oei Tiong Ham's appears to have been, as well as those of several big tycoons of the 1980s) or whether he has just been an "ersatz" rent-seeking capitalist, as Yoshihara claims all Southeast Asian businessmen are, relying primarily on political connections for privileges and subsidies to rake in unearned income. It would be absurd to suggest that such a man has not displayed considerable business skills 
of some kind, but are they the skills of the small-scale towkay or of the modern corporate tycoon? It is not easy to identify any other factor that would account for his astonishingly rapid growth since 1968. The principal sources of cash flow or profits that have enabled his empire to expand so much faster than any of his rivals' are hard to pin down. The Indocement group of cement plants, one of his largest investments, serving the country's leading growth sector, urban construction, has probably lost about as much money in the 1980s as it has generated. Property deals have certainly been bringing in big profits for him, although he is only one of many large-scale operators in that field. The flour and clove monopolies are presumably still lucrative money-spinners for the group but would account for no more than a small part of its growth. His other trading and manufacturing ventures may be yielding high rates of return-many of them were undertaken in conjunction with other leading business groups in recent years-and it may be that the extraordinary diversity of his holdings proved advantageous during difficult times in the mid-1980s, enabling him to snap up bargains. He is said to have picked up many ailing companies that turned to him for help during the economic downturn, so he must have made big capital gains when they returned to profits later. By 1989, Liem's group included more than 243 companies, whereas it had less than one-quarter that number earlier in the decade. His total assets had grown to US\$ 3.5 billion, almost double what they had been a decade earlier. Yet there is a magpie-like quality to these ill-assorted acquisitions, what seems like a grabbing at bargains reminiscent of the old towkay mentality, rather than a sign of deliberately planned corporate logic.

Is Liem at all typical of the other big tycoons of the New Order era? In several respects he is, despite the sheer scale of his activitities and his close links with the palace that make him exceptional. He does not stand in a class apart from his contemporaries in the way that Oei Tiong Ham did by his forward-looking business strategy and managerial techniques. In fact, several others seem to be ahead of him in this respect, the Astra and Dharmala groups, in particular. ${ }^{17}$ The diversity of Liem's vast array of companies is a feature of at least half the second-ranking groups that make up the top fifty, although on a lesser scale. And it may be significant that such diversity is more characteristic of the wheeler-dealer rent-seeking types than of the groups built by the more highly regarded businessmen who have minimized their reliance on political connections.

On the controversial matter of just how much political influence he wields, Liem again differs from other tycoons in degree more than in kind. Almost all promote their special interests at the highest levels they can reach, some vigorously or scandalously, others much less so. Although Liem has certainly had unrivalled access to President Suharto for a long time, it is impossible to assess how far he has been able to impact the determination of the government's economic policies in general, as distinct from particularistic decisions about the allocation of contracts, credits, subsidies, and so on (relatively little in the early years, one would guess, when the technocrats carried more clout, although that may no longer have been the case in the 1980s). Other leading tycoons who seem to have similar access and influence include Bob Hasan, the timber king, Ir. Ciputra, Prayogo Pangestu, the fast-rising pulp and paper baron, now in league with Suharto's daughter, Mbak Tutut, but relatively few others these days. A recent development of potentially great importance has been the

\footnotetext{
${ }^{17}$ Liem's is the only group in the top six that is not based primarily on one line of business but on a bewildering diversity of firms and product lines. Most of the biggest groups have several divisions-real estate, finance, banking, or trading as well as manufacturing - but all others of the top six are relatively concentrated; for instance, the core business of Astra lies unequivocally in auto assembling, of Sinar Mas in palm-oil plantations and cooking oil, of Lippo in banking and finance, whereas the two kretek giants, Djarum and Gudang Garam, are into cigarette-related activities.
} 
tendency for other big business groups to go into partnership with Liem's companies in many of their new ventures, partly as a means of insurance and access to influence or protection, one suspects, so that he is becoming the center of a complex network of new-style patron-client relationships linked indirectly into palace circles.

In short, new elements have constantly been woven into the ever-changing cobweb of personal and financial ties holding the business-political elites together as it has evolved over the last twenty years. And it increasingly seems that Indonesia may be moving toward a pattern of political relationships strikingly similar to Rush's picture of the nineteenthcentury opium kings "nested within the power structures" of Java. Nothing like that had occurred during the intervening hundred years, when the Chinese in Indonesia found themselves out of favor with the authorities, initially colonial, later independent Indonesian, who were trying to change the character of the society in various ways. Perhaps in this respect, the course of Southeast Asian history, after colonial era deviations, is returning to its more natural, earlier, direction. If so, it may be going back to something more like the pattern of political and economic relationships Rush has described, to which one should be looking for clues about the shape of things to come, rather than toward the emergence of a conventionally European-style but predominantly Sino-Indonesian bourgeoisie. 